\title{
The effect of a low-protein ration on milk yield and plasma metabolites in Friesian heifers during early lactation
}

\author{
BY J. D. OLDHAM, W. H. BROSTER, D. J. NAPPER AND \\ J. W. SIVITER \\ National Institute for Research in Dairying, Shinfield, Reading, RG2 $9 A T$
}

\section{(Received 27 November 1978 - Accepted 9 March 1979)}

\begin{abstract}
I. Sixteen first-calf Friesian heifers were used in a continuous treatment design experiment. For 2 weeks after calving they were given a $750 \mathrm{~g}$ concentrate, $250 \mathrm{~g}$ hay $/ \mathrm{kg}$ ration with $\mathrm{I} 69 \mathrm{~g}$ crude protein (nitrogen $\times 6.25 ; \mathrm{CP}) / \mathrm{kg}$ dry matter (DM). They were then divided into two groups of eight and given a high-protein $(223 \mathrm{~g} \mathrm{CP} / \mathrm{kg} \mathrm{DM})$ or low-protein ( $107 \mathrm{~g} \mathrm{CP} / \mathrm{kg} \mathrm{DM})$ ration at the rate of $10.8 \mathrm{~kg}$ concentrates $+3.6 \mathrm{~kg}$ hay for 8 weeks.

2. Milk yield and composition, live weight and blood composition were monitored throughout. A digestibility trial was carried out with six animals on each treatment.

3. The low protein ration reduced DM, organic matter, energy and fibre digestibility significantly $(P<0.001)$ so that intakes of digestible energy were not equal and the low-protein group lost more weight than the highprotein group.

4. Milk yield and the fat content of milk were lower in heifers given the low-protein ration $(P<0.01)$. The lactose content of the milk was not affected and protein content only slightly reduced $(P<0 \cdot \mathrm{I})$ by lowprotein feeding. When the heifers were all changed onto an adequate protein ( $190 \mathrm{~g} \mathrm{CP} / \mathrm{kg} \mathrm{DM}) \mathrm{ration}$ in mid-lactation, those which had previously been under-fed protein appeared to recover in milk yield to the point they might have been expected to reach if given an adequate-protein ration throughout.

5. Concentrations of urea $(P<0.001)$ and albumin $(P<0.05)$ were reduced by underfeeding protein, but albumin concentration was affected less by diet than by stage of lactation. Blood concentrations of total protein, glucose, sodium, potassium, calcium, inorganic phosphate, iron, copper, haemoglobin and packed cell volume were unaffected by treatment. Blood magnesium concentration was slightly lower $(P<0 \cdot I)$ with low-protein feeding.
\end{abstract}

Few studies have been done, under UK feeding conditions, on the effects of low protein intakes on performance of cows early in lactation. This is a critical period in the lactation cycle when food intake often does not adequately match output of nutrients in milk, and body reserves of energy and possibly protein, are drawn on. Artificial manipulation (by abomasal infusion) of protein supply to cows in early lactation has prompted large responses in milk nutrient output (Orskov et al. 1977) even to the extent that negative energy balance was increased.

Only Treacher et al. (I976) have fed low-protein diets (down to $\mathrm{r} 20 \mathrm{~g}$ crude protein (nitrogen $\times 6.25 ; \mathrm{CP}) / \mathrm{kg}$ dry matter (DM)) to cows in early lactation in this country. They began low-protein feeding during gestation so that precalving and lactation effects were confounded.

The effects of low-protein feeding in early lactation have received rather more attention in North America (Sparrow et al. 1973; Chandler et al. 1976; Van Horn et al. 1976), though diets containing less than $125 \mathrm{~g} \mathrm{CP} / \mathrm{kg}$ DM have not been studied.

We wished to study the gross effects of underfeeding of protein to heifers during the first Io weeks of lactation by offering a ration containing less than $110 \mathrm{~g} \mathrm{CP} / \mathrm{kg}$ DM. Where comparable levels of protein have been fed, the experiments have usually not been in early lactation and so may have been conducted in a less sensitive phase of lactation (Thomas, 1971; Polan et al. 1976). The only exception appears to be the work of Drori \& Folman (1970) in Israel who included in their study a diet containing no more than $115 \mathrm{~g} \mathrm{CP} / \mathrm{kg}$ DM for whole lactations. Unfortunately only brief reports of that work are available (Drori \& 
Folman, I970; Drori \& Folman, I973). The indication from those trials was that such a low protein level in the diet was not detrimental to milk production, a conclusion worth re-examining under different feeding conditions.

Our results show that low-protein rations may interfere with milk fat production in early lactation, perhaps partly through changes in fibre digestion, but that compensatory increases in milk yield can be achieved by changing from low- to adequate-protein feeding after 10 weeks of lactation. The efficiency with which protein supply is converted into milk protein can be very high. A preliminary report of this work has been published (Oldham, Broster et al. 1978).

\section{EXPERIMENTA L}

\section{Animals, feeding and management}

Sixteen first-calf Friesian heifers were used. They calved in September or October 1976. Before calving and throughout the experimental period they were housed on rubber mats in concrete standings where they were fed individually and from where uneaten food of individual animals was weighed. Water was freely available.

At 06.00 and I 5.00 hours the animals were milked in their standings and fed half their daily ration of hay plus concentrates. Refusals of food were removed before the afternoon (I5.00 hours) feed.

\section{Treatments}

Diet I (Table I) was fed to all sixteen heifers before calving. Diet 2 (Table 1) was fed to all heifers for the first Io d after calving (period I). This was designed to be a moderate-protein diet (see Table 2) and the level of feeding was increased every $2 \mathrm{~d}$, up to a level of $3.6 \mathrm{~kg}$ hay $+10.8 \mathrm{~kg}$ concentrates $/ \mathrm{d}$ on days $8-10$. On day 11 after calving the heifers were divided at random into two groups of eight and the concentrate part of the ration abruptly changed to either low (LP treatment, Table I)- or high (HP treatment, Table I)-protein content. The level of feeding was then maintained constant at $3.6 \mathrm{~kg}$ hay $+10.8 \mathrm{~kg}$ concentrates $/ \mathrm{d}$ in the period I I-70 d after calving (period 2).

On day 7 I after calving the animals were transferred to another experiment which will be reported separately (J. D. Sutton \& W. H. Broster, unpublished results). They were rerandomized orthogonally onto experimental treatments for that experiment (period 3) so that 'carry-over' effects from period 2 could be identified. The diets used contained either 60 or $90 \%$ concentrates plus hay with whole ration CP content of $190 \mathrm{~g} / \mathrm{kg} \mathrm{DM}$. The level of feeding was constant at $140 \mathrm{MJ} / \mathrm{d}$.

\section{Measurements, sampling and analysis}

Food. Samples $(200 \mathrm{~g})$ of hay and concentrates were taken once each week, dried at $100^{\circ}$, ground and stored. They were analysed for total $\mathrm{N}$ (Kjeldahl), ash cell-wall constituents (CWC; Van Soest \& Wine, I967) and gross energy content.

Intake. Daily refusals of hay or concentrates were estimated by volume and removed except during the digestibility trial (below) when refusals were removed and weighed.

Milk. Weight at each milking was recorded. Each week two samples bulked in proportion to yield were prepared, one for Monday afternoon - Wednesday morning and one for Wednesday afternoon - Friday morning milkings. These were analysed for total solids, fat, protein and lactose (IRMA; Grubb Parsons Ltd, Newcastle-upon-Tyne).

Live weight. The heifers were weighed on Monday, Wednesday and Friday each week after calving. Mean weekly live weights were calculated.

Blood samples. Up to day 70 jugular venous blood samples were taken into heparinized Vacutainers (Becton-Dickinson Ltd), three times every 2 weeks on Monday, Friday and Wednesday in sequence. The samples were always taken between $09 \cdot 30$ and 10.30 hours. 
Table I. The composition $(\mathrm{g} / \mathrm{kg})$ of concentrates fed and the amounts of hay and concentrates offered

\begin{tabular}{|c|c|c|c|c|}
\hline Ration ... & $\mathbf{I}$ & 2 & LP & HP \\
\hline \multicolumn{5}{|l|}{ Concentrates } \\
\hline Rolled barley & 864 & 400 & 600 & 200 \\
\hline Soya-bean meal & - & 200 & - & 400 \\
\hline Flaked maize & - & 250 & 250 & 250 \\
\hline Sugar beet pulp & - & 100 & 100 & 100 \\
\hline Decorticated groundnut meal & 102 & - & - & - \\
\hline Fish meal & $5 \mathbf{I}$ & - & - & - \\
\hline Vitamin-mineral supplements & II & - & - & - \\
\hline Nutramol $\uparrow+$ supplements $*$ & - & 50 & 50 & 50 \\
\hline Hay $(\mathrm{kg} / \mathrm{d})$ & 5 & $\begin{array}{l}3 \text { increasing } \\
\text { to } 3.6\end{array}$ & $3 \cdot 6$ & $3 \cdot 6$ \\
\hline Concentrates $(\mathrm{kg} / \mathrm{d})$ & 5 & $\begin{array}{l}3 \text { increasing } \\
\text { to } 10.8\end{array}$ & 10.8 & $10 \cdot 8$ \\
\hline
\end{tabular}

LP, Low protein; HP, high protein. (1965)

* To provide daily requirements of vitamins and minerals as stated by Agricultural Research Council

$\dagger$ Molassed peat; Rumenco Ltd, Burton-on-Trent.

Table 2. The composition of hay and concentrates used before and during the first $70 d$ after parturition

\begin{tabular}{lccccc} 
& Hay & \multicolumn{4}{c}{ Concentrates } \\
\cline { 3 - 6 } & & I & 2 & LP & HP \\
Ration* $\ldots$ & 849 & 948 & 855 & 853 & 855 \\
Dry matter (DM) (g/kg) & & & & & \\
Constituents (g/kg DM) & IOI & I13 & 192 & 108 & 260 \\
CP & 631 & nd & 214 & 297 & 206 \\
CWC & 924 & 876 & 947 & 967 & 948 \\
OM & I8.02 & nd & 17.94 & 17.68 & 18.40
\end{tabular}

LP, Low protein, HP, high protein; nd, not determined; CP, crude protein (nitrogen $\times 6.25$ ); CWC, cell wall constituents (Van Soest \& Wine, 1967). OM, organic matter.

* For details, see Table I.

Samples of whole blood were analysed for packed cell volume (PCV), haemoglobin (Hb), and plasma was prepared by centrifugation for analysis for urea, glucose, inorganic phosphate, calcium $(\mathrm{Ca})$, magnesium $(\mathrm{Mg})$, sodium $(\mathrm{Na})$, potassium $(\mathrm{K})$, copper $(\mathrm{Cu})$, albumin and total protein. The methods were those of Rowlands et al. (1974).

Digestibility of $D M$, energy, organic matter $(O M), N$ and $C W C$. Between the fifth and ninth week of lactation, a Io d collection of faeces was made on six animals fed each of diets HP and LP. Faeces was collected using bags and harness. Subsamples of faeces were dried and stored for analysis of OM, gross energy and CWC. Wet samples of faeces were stored in sulphuric acid $(2 \cdot 8 \mathrm{M})$ for $\mathrm{N}$ analysis.

Statistical analysis. The experiment used a continuous treatment design and differences between treatment means in period 2 were analysed by analysis of variance (Snedecor \& Cochran, 1967 ). Period I (days 0-10 after calving) was used to adjust by covariance, treatment means for milk yield, milk composition, milk component yield and blood urea, albumin total protein, glucose and $\mathrm{Mg}$. No covariance adjustment was applied to other variates. 


\section{RESULTS \\ Food intake and digestibility}

The amounts of uneaten food on the HP treatment were very small. Some hay was uneaten by all LP heifers so that DM intake was significantly $(P<0.0 \mathrm{I})$ lower on the LP treatment though the difference was not great (Table 3). The hay used had a higher ash content than the concentrates (Table 2); as only hay was refused OM intakes were not significantly different.

The LP treatment significantly reduced digestibility of DM, OM, energy and fibre (CWC). The reduction in fibre digestion accounted almost completely for reduction in DM digestion. This would account for the amounts of uneaten hay on the treatment.

As a result of the differences in $\mathrm{OM}$ and energy digestibilities, digestible organic matter (DOM) and digestible energy (DE) intakes were significantly $(P<0.001)$ lower for LP treatment (Table 3). It was calculated that these intakes of DE were equivalent to intakes of $137 \mathrm{MJ}$ metabolizable energy (ME)/d for HP and I I MJ ME/d for LP treatment.

\section{Milk yield}

LP heifers yielded less milk $(P<0.01)$ than HP heifers (Table 4 and Fig. I) in the main experimental period (period 2 ).

Subsequently (period 3) when the LP and HP heifers were re-randomized to other diets, LP heifers increased daily milk yield in a compensatory manner while the yield of milk from HP heifers decreased (Fig. I) so that mean yield for LP heifers was greater than mean yield for HP heifers in period 3 .

This surprising result in period 3 may be attributable in part to the effects of the digestibility trials started in week 5-6 of lactation. From this point yields for HP heifers started to decrease more rapidly than might be expected (Broster, Broster et al. 1969) (Fig. I) while yields for LP heifers did not, implying that the higher-yielding HP heifers may have been more vulnerable to the stress of collection of faeces by the use of harness and bags.

\section{Milk composition}

The variations in milk fat, protein and lactose content up to the end of period 2 are shown in Fig. 2. Treatment means (Table 4 ) in period 2 were not significantly different for milk lactose content; LP heifers produced milk of only slightly lower protein content than HP heifers $(P<0.1)$ Milk fat content was significantly $(P<0.01)$ lower for LP heifers than for HP heifers.

The yields of milk lactose $(P<0.01)$ and protein $(P<0.001)$ were significantly lower for LP heifers in similar proportion to the differences in milk yield. As both milk yield and milk fat content were significantly higher for HP heifers the yield of milk fat was much greater $(P<0.00 \mathrm{I})$ for HP heifers.

\section{Live weight and live weight change}

All heifers lost weight up to the end of period 2 (Fig. 3). Mean live weights in the experimental period (period 2) were $488 \mathrm{~kg}$ (LP treatment), $505 \mathrm{~kg}$ (HP treatment; SE of difference $\pm 9 \cdot 2 \mathrm{~kg}$ ). These differences were only significant at $P<0 \cdot \mathrm{I}$.

Live weight loss in the period $14-67 \mathrm{~d}$ after calving (the middle of the second to the middle of the ninth weeks after calving) were $-48.6 \mathrm{~kg}$ (LP treatment) and $-23.8 \mathrm{~kg}$ (HP treatment; SE of difference $\pm \mathrm{II} \cdot \mathrm{I} \mathrm{kg})$. The live weight loss was significantly $(P<0.0 \mathrm{I})$ greater for $\mathrm{LP}$ heifers. 


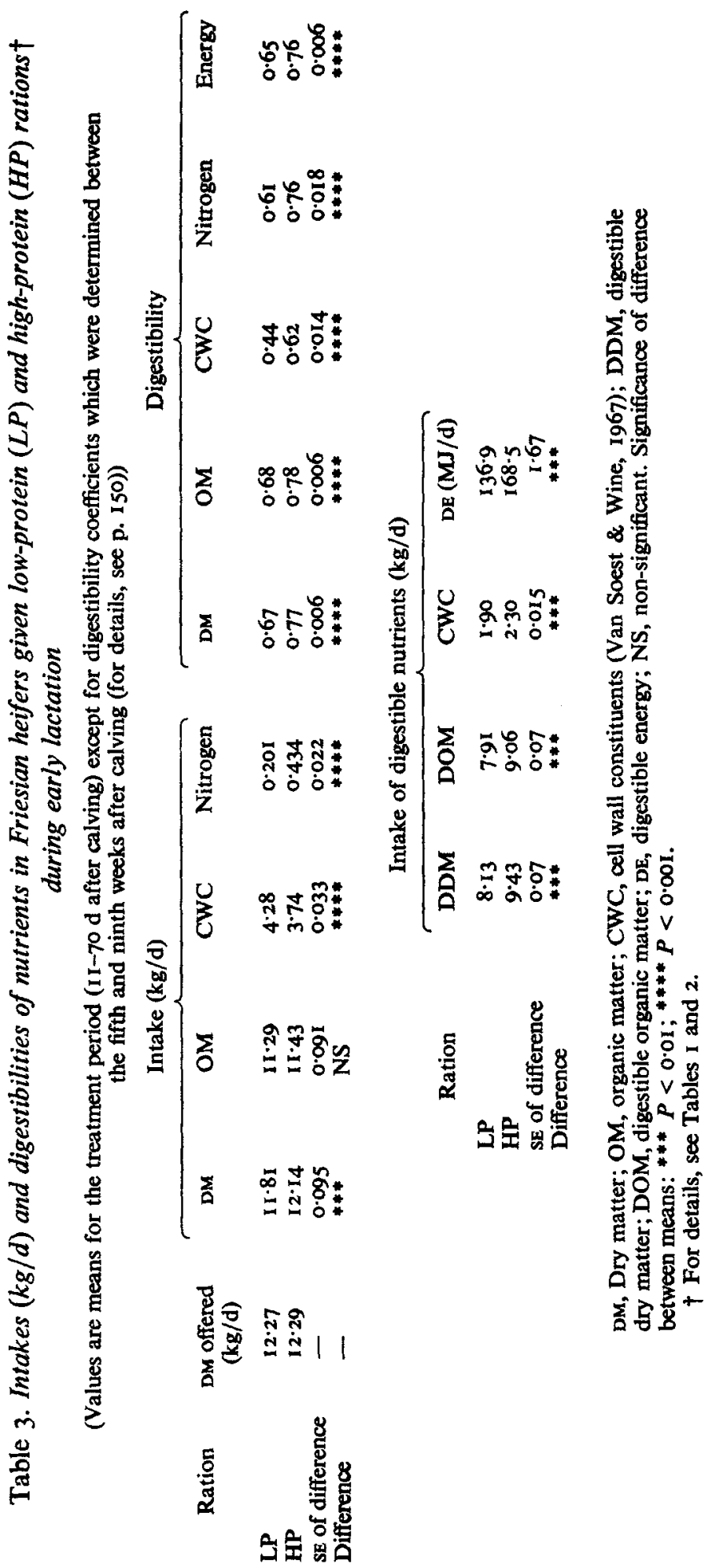


Table 4. Milk yield $(\mathrm{kg} / \mathrm{d})$ and composition $(\mathrm{g} / \mathrm{kg})$ and the yield of milk fat, protein and lactose in Friesian heifers given low-protein $(L P)$ and high-protein $(H P)$ rations during early lactation

(Values are means for the treatment period (I I-70 $\mathrm{d}$ after calving))

\begin{tabular}{|c|c|c|c|c|c|c|c|}
\hline \multirow[b]{2}{*}{ Ration } & \multirow{2}{*}{$\begin{array}{l}\text { Milk yield } \\
(\mathrm{kg} / \mathrm{d})\end{array}$} & \multicolumn{3}{|c|}{ Milk composition $(\mathrm{g} / \mathrm{kg}$ ) } & \multicolumn{3}{|c|}{ Yield $(\mathrm{g} / \mathrm{d})$} \\
\hline & & Fat & Protein & Lactose & Fat & Protein & Lactose \\
\hline LP & 20.9 & $36 \cdot 6$ & 28.9 & $47 \cdot 7$ & 758 & 612 & 1002 \\
\hline HP & $24 \cdot 4$ & $43 \cdot 5$ & $30 \cdot I$ & $47 \cdot 8$ & 1066 & 728 & 1158 \\
\hline SE of difference & I.04 & $2 \cdot 0$ & 0.07 & 0.06 & $66 \cdot 3$ & $26 \cdot 2$ & $47 \cdot 6$ \\
\hline Difference & *** & *** & * & NS & $* * * *$ & $* * * *$ & $* * *$ \\
\hline
\end{tabular}

NS, Non-significant. Significance of difference between means: $\quad P<0.1$; $* * * P<0.01$; **** $P<0.001$.

$\dagger$ For details, see Tables $\mathrm{I}$ and 2.

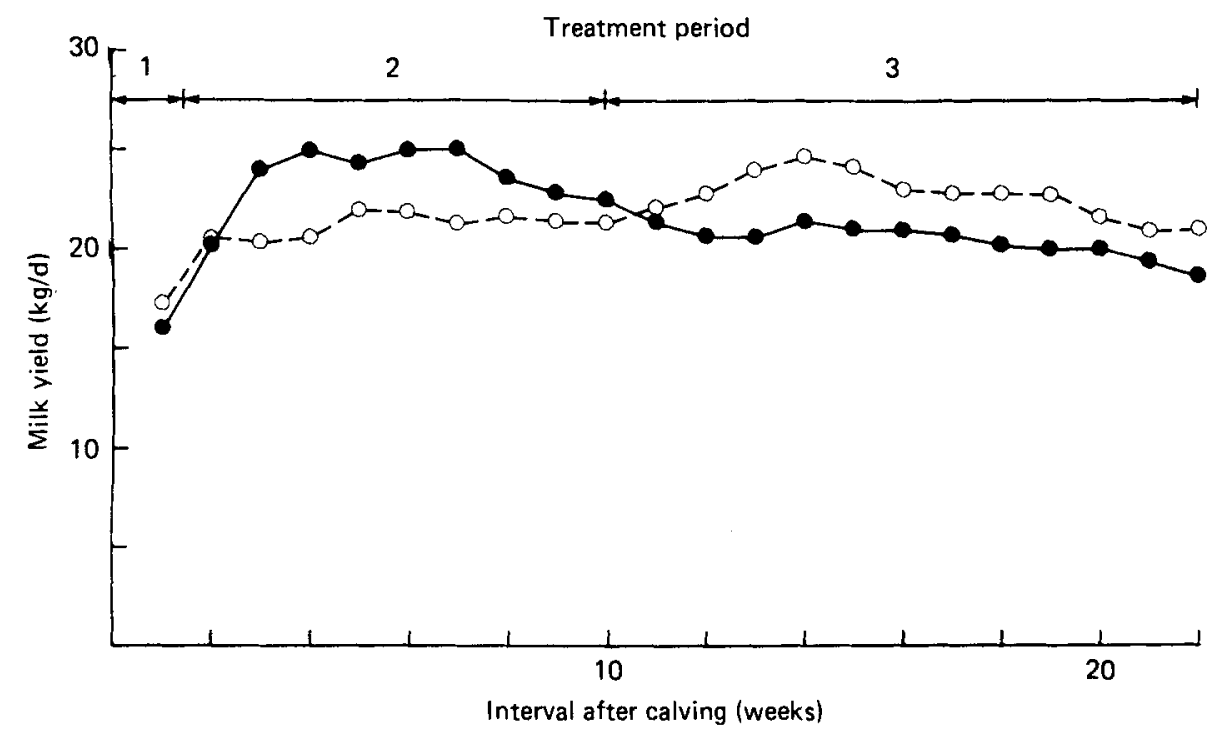

Fig. I. Milk yield (kg/d) of heifers given low-protein (LP) $(O)$ or high-protein (HP) (O) rations during early lactation. In period $\mathrm{I}$ all animals received the same control ration before receiving LP or HP rations in period 2. Period 3 began at week 10 after calving, when all heifers were re-randomized onto rations containing $190 \mathrm{~g}$ crude protein (nitrogen $\times 6.25$ ) $/ \mathrm{kg}$ dry matter; for further details, see p. I 50. For details of rations, see Tables $I$ and 2.

\section{Blood constituents}

Treatment means for all measured constituents are shown in Table 5. HP treatment produced significantly higher mean concentrations of urea $(P<0.001)$ and albumin $(P<0.05)$ in blood than LP treatment. Mean blood $\mathrm{Mg}$ was also slightly higher $(P<0.1)$ for $\mathrm{HP}$ treatment than LP treatment. Other blood constituents did not differ between treatments (Table 5). Blood urea concentration fell to very low levels in the LP heifers (Fig. 4).

Stage of lactation effects were greater than treatment differences for albumin and total protein (Fig. 5) both of which rose gradually until the fifth to sixth week after parturition.

$\mathrm{Hb}$ tended to fall after parturition while blood glucose rose slightly (Fig. 5). There was no change in blood PCV up to the end of period 2. 

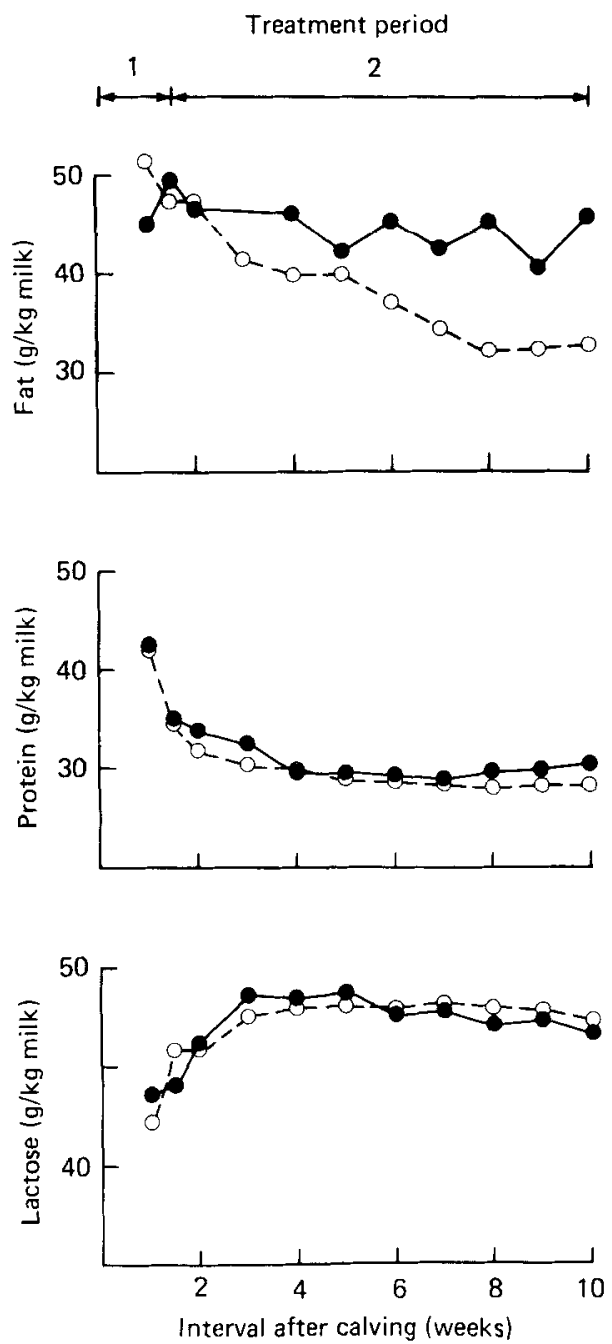

Fig. 2. Variation with interval after calving (weeks) of the mean concentrations $(\mathrm{g} / \mathrm{kg}$ milk) of fat, protein and lactose produced by groups of heifers given low-protein (LP) (O) or high-protein (HP) ( ) rations during early lactation. In period I all animals received the same control ration before receiving LP or HP rations in period 2; for further details, see p. 150. For details of rations, see Tables $I$ and 2.

\section{DISCUSSION}

The reduction in fibre digestion observed with the LP ration is in agreement with known effects of low-protein diets on fibre digestion and forage consumption (Balch \& Campling, 1962) and suggests that this ration did not supply the rumen microbial population with sufficient $\mathrm{N}$ to maintain maximal rates of cellulose digestion and microbial growth. If rumen needs for degradable $\mathrm{N}(\mathrm{g} / \mathrm{d}$ ) were $\mathrm{I} \cdot 25 \times \mathrm{MJ} \mathrm{ME}$ intake (Roy et al. 1977) and 


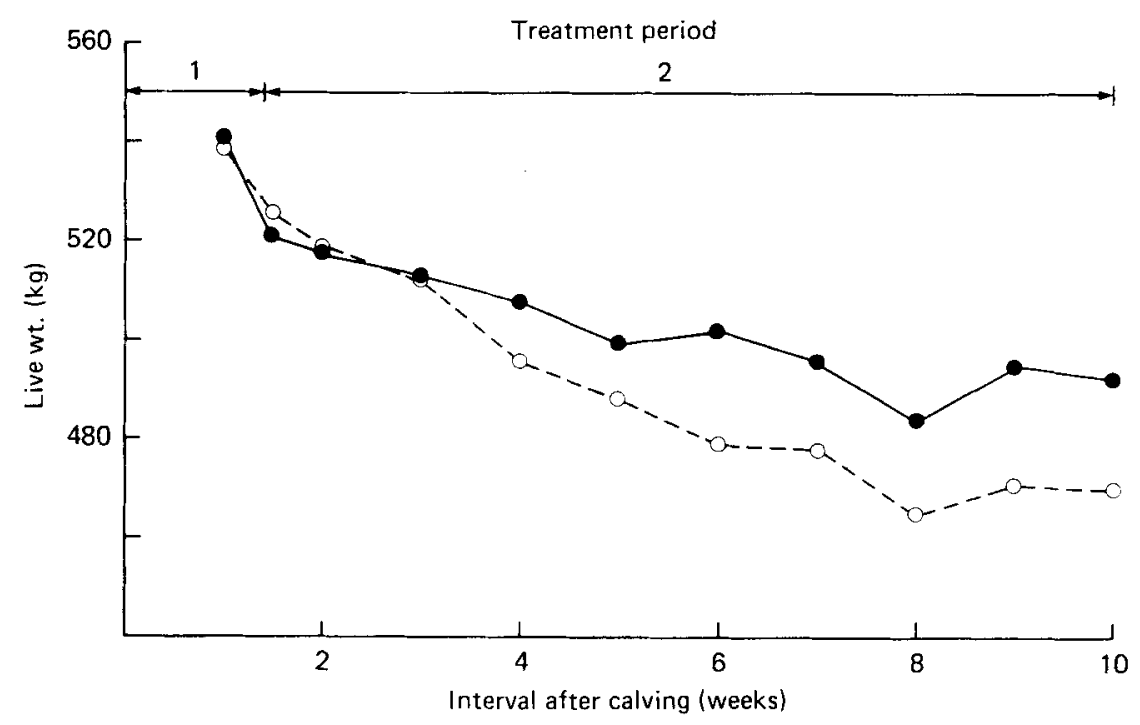

Fig. 3. Mean live weights $(\mathrm{kg})$ of heifers given low-protein (LP) $(\mathrm{O})$ or high-protein $(\mathrm{HP})(\mathrm{O})$ rations from day $\mathrm{I}$-70 after calving. All animals received the same ration in the first Io $d$ after calving (period I); for further details, see p. I50. For details of rations, see Tables 1 and 2.

assuming that the potential intake of ME from the LP ration was the same as that from the HP ration ( $137 \mathrm{MJ} \mathrm{ME} / \mathrm{d}$ ) than 0.8 of the $\mathrm{N}$ in the LP ration would need to have been 'degraded' in the rumen to meet microbial $\mathrm{N}$ needs. With the further assumption that at the measured ME intake for the LP ration (I I MJ ME/d) the ratio of $1.25 \mathrm{~g} \mathrm{~N} / \mathrm{MJ}$ ME intake for rumen microbial $\mathrm{N}$ need was just maintained it can be calculated that only 0.7 of the $\mathrm{N}$ in the LP ration was degraded in the rumen. According to these calculations the rumen degradable N (RDN) content of the LP ration was therefore insufficient to meet microbial needs for $\mathrm{N}$ at an ME allowance of $137 \mathrm{MJ} \mathrm{ME} / \mathrm{d}$, so that reduced fibre digestion, and consequently food intake, with the LP ration was not surprising. A ration containing $125-130 \mathrm{~g} \mathrm{CP} / \mathrm{kg}$ ration DM would have been needed to meet microbial $\mathrm{N}$ needs (Roy et al. 1977) if ME intake was $137 \mathrm{MJ} / \mathrm{d}$ and 0.7 of the ration $\mathrm{N}$ was rumen degradable.

Because two extreme treatments only were used in this experiment it is not possible to identify those points of adequacy of protein supply which optimise fibre digestion and intake. These calculations suggest relatively low limiting values but responses in intake of concentrate diets to protein increments above $\mathrm{I} 43 \mathrm{~g} \mathrm{CP} / \mathrm{kg}$ DM have been found in both lambs and dairy cows (Ørskov et al. 197I ; Hassan \& Roussel, 1975). Other work with cows has indicated that intake is maximal with rations containing $130 \mathrm{~g} \mathrm{CP} / \mathrm{kg}$ DM (Polan et al. 1976) which represents good agreement with the calculations. It is clear from the present work that fibre digestion can be severely impaired when the ration contains less than I $10 \mathrm{~g} \mathrm{CP} / \mathrm{kg} \mathrm{DM}$, and that intake is reduced.

The difference in DE intakes between LP and HP heifers confounds energy and protein responses and makes it impossible to isolate protein effects. The difference in milk yields of $3.5 \mathrm{~kg} / \mathrm{d}$ was consistent with established effects of level of energy intake on milk production in early lactation (Broster, Broster et al. I 969).

Other workers (Drori \& Folman, 1970; Treacher et al. 1976; Thomas, 1971) did not include digestibility measurements in their experiments so that effects attributed to protein intake differences may have been affected by energy intakes in those experiments also. It 


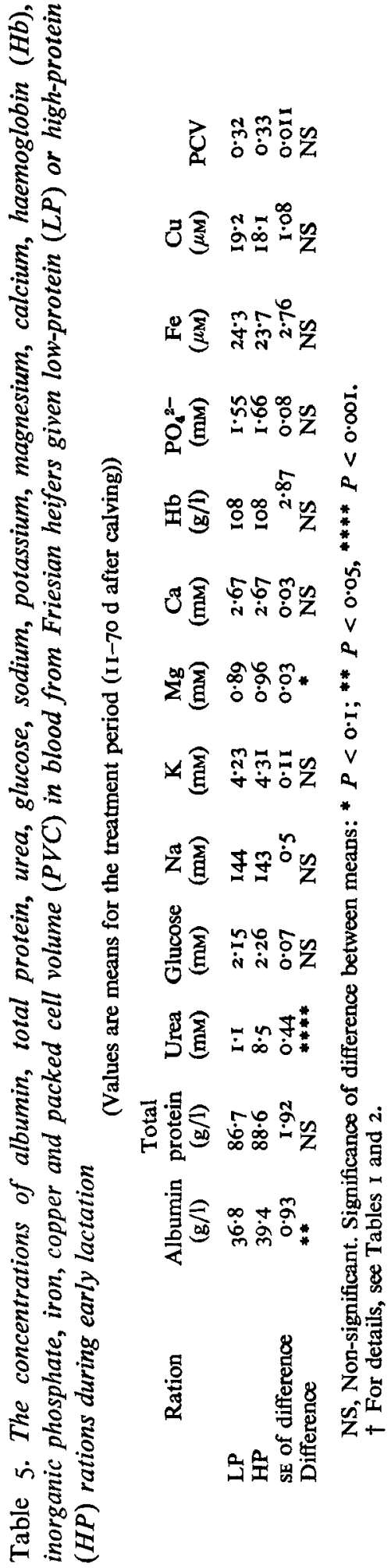



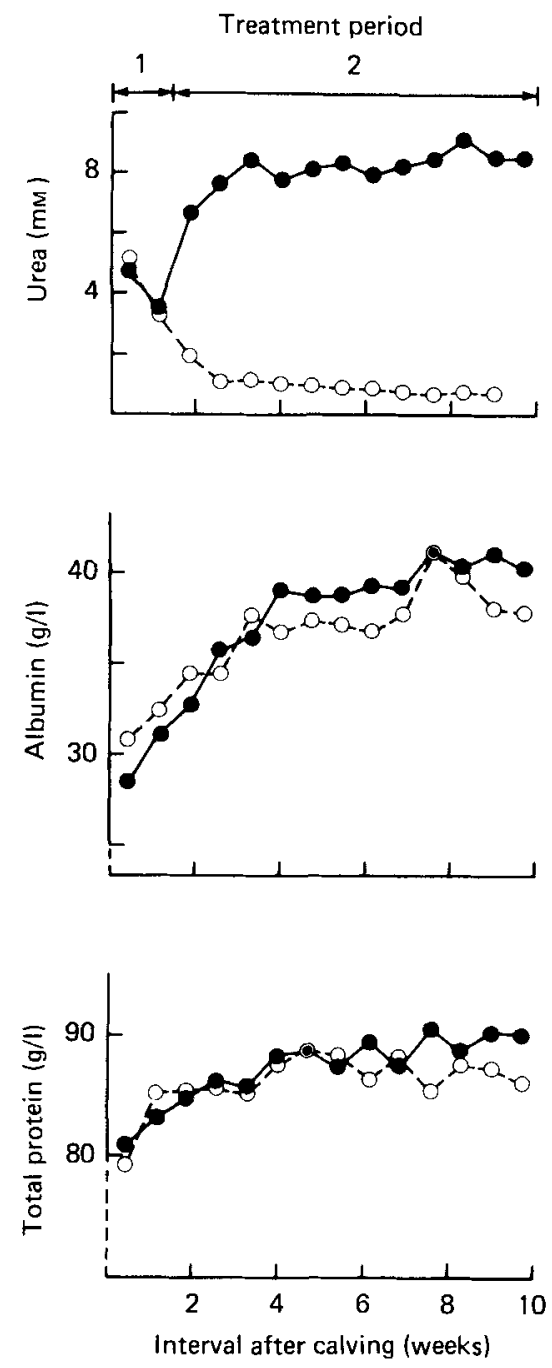

Fig. 4. Variation, with interval (weeks) after calving, of the mean concentration of urea (mm), albumin $(\mathrm{g} / \mathrm{l})$ and total protein $(\mathrm{g} / \mathrm{l})$ in blood plasma from heifers given a control ration for the first Io d after calving (period 1 ), then either a low-protein (LP) (O) or high-protein (HP)(O) ration up to day 70 after calving (period 2); for further details, see p. 150. For details of rations, see Tables $\mathrm{I}$ and 2.

seems unlikely that this was the case in Drori \& Folman's (1970) experiments when milk yield was not affected by dietary protein concentrations ranging from $115-160 \mathrm{~g} / \mathrm{kg} \mathrm{DM}$; their diets did, however, contain a higher proportion of concentrates than those used here. They concluded that allowing protein for maintenance and for growth after first calving, values for the ratio digestible crude protein (DCP): milk protein for the cows on the lowprotein treatment ranged from $I \cdot I 5-I \cdot 35$. The corresponding value for LP treatment in the present study was 0.97 . Even though DCP is not a good index of protein supply (Broster \& Oldham, 1977) our results with LP substantiate those of Drori \& Folman (1970) to the extent that milk protein output per unit protein supplied to the body can be a very efficient process. 

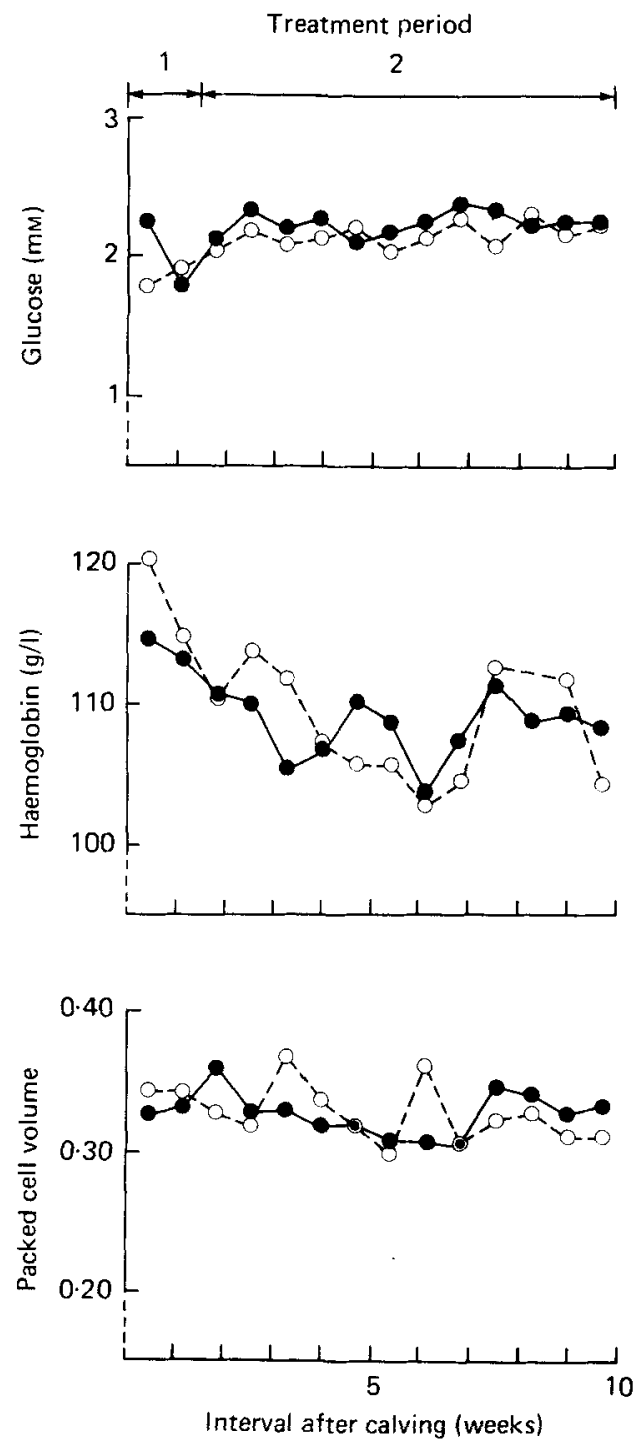

Fig. 5. Variation, with interval (weeks) after calving, of the mean concentration of glucose (mM) in blood plasma and haemoglobin $(\mathrm{g} / \mathrm{l})$ and of packed cell volume in blood of heifers given a control ration for the first Io d after calving (period I) then either a low-protein (LP) ( $O$ ) or high-protein (HP) (O) ration up to day 70 after calving (period 2); for further details, see p. I 50. For details of rations, see Tables $I$ and 2.

An alternative to the ratio, milk protein output:DCP above maintenance as a measure of the efficiency of milk protein production is the calculation of the efficiency of utilization of absorbed protein for milk protein production.

The efficiency of utilization of absorbed protein (EPU; Oldham, I978) can be calculated by relating absorbed protein (calculated according to Broster \& Oldham, 1977) to milk protein output, taking the differences in rates of body-weight loss into account. On this basis EPU was 0.70 and 0.53 for the LP and HP rations, respectively. The value for the HP ration is low compared with direct measurements of EPU made in this laboratory with 
high-yielding dairy cows in early lactation (Bruckental et al. 1978). A value of 0.70 was not abnormally high, but agreed well with an average value of 0.73 for cows 4 weeks after calving (Bruckental et al. 1978).

A compensatory rise in milk yield on changing from low to higher protein levels in the diet as seen in period 3 of this experiment, has not previously been noted. A similar response can be achieved by changing plane of nutrition at this stage in lactation (Broster, Broster et al. 1969) and it seems likely that the response here was to restoration of adequate fibre digestion and energy intake on increasing the protein content of the ration. The shape of the lactation curve of HP heifers was abnormal and it appeared that production in these animals was affected by the stress of the digestibility trial and loss in milk yield, as a result of this stress, was not subsequently recovered. Milk yield of the LP heifers in period 3 was probably close to the yield the HP heifers would have achieved if the lactation curve had been normal (Wood, 1977).

The protein content of diets has not generally been regarded as a factor affecting milk fat content. The difference observed here was large and indicated an increase in fat content with the HP ration and a normal fat content with the LP ration in comparison with heifers given similar amounts of a $750 \mathrm{~g}$ concentrate, $250 \mathrm{~g}$ hay $/ \mathrm{kg}$ ration at this Institute (Broster et al. 1977). It is possible that at least part of this difference was related to the difference in fibre digestion observed. The relative rates of acetate and propionate production in the rumen may have been affected with consequent effects on milk fat synthesis (Sutton, 1976). As milk fat content with LP ration was not abnormally low, it is suggested that rumen effects were not entirely responsible for the difference, though unfortunately we did not sample rumen contents in these heifers. Measurements of the concentration in blood of low-density lipoproteins $\left(\mathrm{LDL}_{1}\right)$, showed very high levels in the LP heifers with much lower levels in the HP heifers (Stead \& Oldham, 1978). The difference in live weight loss probably reflected differences in adipose tissue mobilization so that higher rates of production of $\mathrm{LDL}_{1}$ would have been expected with the $\mathrm{LP}$ treatment. Though $\mathrm{LDL}_{1}$ is not the major carrier of triglyceride for milk fat synthesis, it is a substantial contributor (Glascock \& Welch, 1974) and the difference in blood concentration may suggest that translation of precursor into milk fat was facilitated in the HP ration while an unknown factor interfered on the LP ration. When Ørskov et al. (1977) altered protein supply to cows in early lactation by infusing casein per abomasum milk fat content as well as milk and milk protein output was dramatically increased. Other workers have not produced milk fat responses from casein infusion in mid- or late-lactation experimenta (Clark, 1975).

In feeding experiments in mid-lactation, protein effects on milk fat content have not been recorded (e.g. Broster et al. 1969; Gordon, 1977). But in early lactation Sparrow et al. (1973) increased milk fat content from 3.2 to 3.5 by increasing protein content of ration from 135 to $175 \mathrm{~g} / \mathrm{kg}$ DM and in a complete lactation experiment, Chandler et al. (I976) noted a difference in milk fat content between diets of 125 and $155 \mathrm{~g} \mathrm{CP} / \mathrm{kg}$ DM and the difference in milk fat content was greater during early lactation. So it would seem that cows in the early lactation phase are more sensitive to protein inputs and that at this time, protein supply may interact with fat metabolism and possibly influence energy partition (Ørskov et al. 1977). The effects of changing protein supply on endocrine balance are probably relevant here (Oldham et al. 1978).

It is interesting to note that in a recent experiment where sows were fed on diets containing 90,130 or $170 \mathrm{CP} / \mathrm{kg}$ from parturition, the milk produced at $25 \mathrm{~d}$ lactation contained 55,63 and $7 \mathrm{I} \mathrm{g}$ fat $/ \mathrm{kg}$ respectively, but at $4 \mathrm{I} \mathrm{d}$ the values were 58,55 and $68 \mathrm{~g} / \mathrm{kg}$ (Greenhalgh et al. 1977). Limited evidence had previously led Elsley (1972) to conclude that the composition of cows' milk was unaffected by changes in dietary intake of $\mathrm{CP}$, but he did not comment on stage of lactation effects. 
Milk lactose and protein contents were little affected by the LP treatment. Though protein content was a little lower with LP treatment this was probably more related to the difference in ME intake than to protein (Rook \& Line, I96I). Treacher et al (1976) noted a lower lactose content in the milk of cows underfed protein in early lactation. It seems likely that this also would have been a result of lower energy intake with low protein feeding but they did not measure digestibility of the rations fed. Underfeeding can reduce milk lactose (Wright et al. 1974) but no effect was seen in the present work.

The changes in milk fat, protein and lactose content with stage of lactation (Fig. 2) were typical of accepted trends (Oldham \& Sutton, 1979). So too were the changes in blood albumin content, being lower immediately after calving (Little, 1974; Treacher et al. 1976). The changes we found in blood $\mathrm{Hb}$ and PCV were not as great as those seen by Treacher et al. (1976) who suggested that their observations confirmed that $\mathrm{Hb}, \mathrm{PCV}$ and albumin levels may not respond to chronic protein deficiency for several weeks. Our results substantiate this. The concentrations of other metabolites, apart from urea, were not affected by protein level, though this of course does not imply that rates of production or utilization were unaffected. The very low urea concentrations found with LP suggest very efficient utilization of amino- $\mathrm{N}$ at the tissue level.

The authors are grateful to $\mathrm{Mr}$ E. Florence and his staff for milk and food analyses and to Mr R. Manston and his staff at IRAD, Compton for blood analyses.

\section{REFERENCES}

Agricultural Research Council (1965). The Nutrient Requirements of Farm Livestock, No. 2, Ruminants. London: HMSO.

Balch, C. C. \& Campling, R. C. (1962). Nutr. Abstr. Rev. 32, 669.

Broster, W. H., Broster, V. J. \& Smith, T. (1969). J. agric. Sci., Camb. 72, 229.

Broster, W. H. \& Oldham, J. D. (1977). In Nutrition and the Climatic Environment, pp. 123-53 [W. Haresign, H. Swan and D. Lewis, editors]. London: Butterworths.

Broster, W. H., Sutton, J. D., Bines, J. A., Smith, T., Siviter, J. W. \& Broster, V. J. (1977). Proc. Nutr. Soc. 36, 145A.

Broster, W. H., Tuck, V. J., Smith, T. \& Johnson, V. W. (1969). J. agric. Sci., Camb. 72, I3.

Bruckental, I., Oldham, J. D. \& Sutton, J. D. (I978). Proc. Nutr. Soc. 37, 107A.

Chandler, P. T., Brown, C. A., Johnston, R. P., MacLeod, G. K., McCarthy, R. D., Moss, B. R., Rakes, A. H. \& Satter, L. D. (1976). J. Dairy Sci. 59, 1897.

Clark, J. H. (1975). J. Dairy Sci. 58, 1 178.

Drori, D. \& Folman, Y. (1970). Proc. I8th int. Dairy Congr. p. 84.

Drori, D. \& Folman, Y. (1973). Israeli-Swedish Seminar in Dairy Husbandry, Agricultural College, Sweden. Rep. no. 26.

Elsley, F. W. H. (1972). In Handbuch der Tierernährung, vol. 2, pp. 330-340. Hamburg: Paul Parey.

Glascock, R. F. \& Welch, V. A. (1974). J. Dairy Sci. 57, 1364.

Gordon, F. J. (1977). Anim. Prod. 25, I8I.

Greenhalgh, J. F. D., Elsley, F. W. H., Grubb, D. A., Lightfoot, A. L., Saul, D. W., Smith, P., Walker, N., Williams, D. \& Yeo, M. L. (1977). Anim. Prod. 24, 307.

Hassan, A. \& Roussel, J. D. (1975). J. agric Sci., Camb. 85, 409.

Little, W. (1974). Res. vet. Sci. 17, 193.

Oldham, J. D. (1978). In Ruminant Digestion and Feed Evaluation, chapter I3, pp. I-I4. [D. F. Osbourn, D. E. Beever and D. J. Thomson, editors]. London: Agricultural Research Council.

Oldham, J. D., Broster, W. H. \& Siviter, J. W. (1978). Proc. Nutr. Soc. 37, 44A.

Oldham, J. D., Hart, I. C. \& Bines, J. A. (1978). Proc. Nutr. Soc. 37, 9A.

Oldham, J. D. \& Sutton, J. D. (1979). In Feeding Strategy for the High Yielding Dairy Cow [W. H. Broster and H. Swan, editors]. St Albans: Granada.

Ørskov, E. R., Fraser, C. \& MacDonald, I. (1971). Br. J. Nutr. 25, 225.

Ørskov, E. R., Grubb, D. A. \& Kay, R. N. B. (1977). Br. J. Nutr. 38, 397.

Polan, C. W., Miller, C. N. \& McGilliard, M. L. (1976). J. Dairy Sci. 59, I9Io.

Rook, J. A. F. \& Line, C. (I96I). Br. J. Nutr. 15, I09.

Rowlands, G. J., Little, W., Manston, R. \& Dew, S. M. (1974). J. agric. Sci., Camb. 83, 27. 
Roy, J. H. B., Balch, C. C., Miller, E. L., Ørskov, E. R., \& Smith, R. H. (I977). In Proceedings of the 2nd International Symposium on Protein metabolism and Nutrition, pp. 126-130. Centre for Agricultural Publishing and Documentation, Wageningen.

Snedecor, G. W. \& Cochran, W. G. (1967). In Statistical Methods, 6th ed. Ames, Iowa: Iowa State University Press.

Sparrow, R.C., Heinken, R. W., Jacobson, D. R., Button, F. E. \& Enlow, C. M. (1973). J. Dairy Sci. 56, 664. Stead, D. \& Oldham, J. D. (1978). Proc. Nutr. Soc. 3745 A.

Sutton, J. D. (1976). In Principles of Cattle Production, pp. 121-143 [H. Swan and W. H. Broster, editors]. London: Butterworths.

Thomas, J. W. (197I). J. Dairy Sci. 54, 1629.

Treacher, R. J., Little, W., Collis, K. A. \& Stark, A. J. (1976). J. Dairy Res. 43, 357.

Van Horn, H. H., Olaloku, E. A., Flores, J. R., Marshall, S. P. \& Bachman, K. C. (1976). J. Dairy Sci. 59, 902.

Van Soest, P. J. \& Wine, R. H. (1967). J. Ass. off. analyt. Chem. 50, 50.

Wood, P. D. P. (1977). J. agric. Sci., Camb. 88, 333.

Wright, J. A., Rook, J. A. F. \& Wood, P. D. P. (I974). J. Dairy Res. 41, 155. 